\title{
Onychomycosis and Erectile Dysfunction. Does Common Etiology Cause Togetherness?
}

\section{Onikomikoz ve Erektil Disfonksiyon. Ortak Etiyoloji Birlikteliğe Neden Olur mu?}

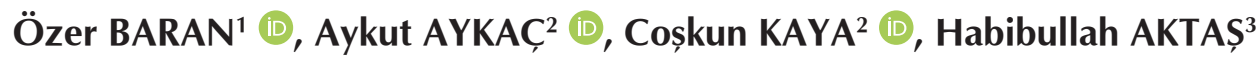 \\ ${ }^{1}$ Karabuk University Faculty of Medicine, Department of Urology, Karabük, Turkey \\ ${ }^{2}$ Eskișehir City Hospital, Department of Urology, Eskișehir, Turkey \\ ${ }^{3}$ Karabuk University Faculty of Medicine, Department of Dermatology, Karabük, Turkey \\ ORCID ID: Özer Baran 0000-0001-9799-8134, Aykut Aykaç 0000-0001-7078-0135, Coșkun Kaya 0000-0002-7445-2304, \\ Habibullah Aktaș 0000-0001-9239-1659
}

Cite this article as: Baran Ö et al. Onychomycosis and Erectile Dysfunction. Does Common Etiology Cause Togetherness? Med J West Black Sea. 2021;5(2):256-260.

Corresponding Author

Özer Baran

E-mail

ozerbaran@karabuk.edu.tr
Received

10.02.2021

Revision

13.03.2021

Accepted

31.03.2021

\begin{abstract}
Aim: We tried to determine the frequency of co-occurrence of erectile dysfunction (ED) and Onychomycosis (OM).

Material and Methods: The sociodemographic form and IIEF- 5 form were filled by the male patients who were admitted to the Urology Polyclinic of Karabük University Medical Faculty with the complaints of ED between April 2019 - April 2020. The patients with ED were included in the study. All the male patients were divided into three groups as mild, moderate and severe according to ED severity. The dermatologist (H.A) examined the presence of OM by taking samples from the toenails of the male patients.
\end{abstract}

Results: Looking at the IIEF-5 scores of 95 patients accepted to the study, it was found that $22(23.1 \%)$ had mild, $20(21 \%)$ moderate and $53(55.9 \%)$ severe ED. Smoking history was higher in the severe ED group $(p<0.001)$. It was found that a total of $32(33.7 \%)$ patients had OM. However, there was no relationship between the severity of ED and the presence of OM $(p>0.114)$.

Conclusion: Erectile dysfunction and OM disease can often be seen together. However, no relationship was found with the severity of ED.

Keywords: Onychomycosis, Erectil disfunction, Etiology

Öz

Amaç: Erektil Disfonksiyon (ED) ile Onikomikoz (OM) hastalığının birlikte görülme sıklığını saptamaya çalıştık.

Gereç ve Yöntemler: Nisan 2019 - Nisan 2020 tarihleri arasında Karabük Üniversitesi Tıp Fakültesi Üroloji Polikliniği'ne ED şikâyeti ile başvuran erkek hastalara sosyodemografik form ve IIEF-5 formu doldurtuldu. ED saptanan hastalar çalışmaya dahil edildi. Tüm erkekler ED ciddiyetine göre hafif, orta, ciddi olmak üzere üç gruba ayrıldı. Dermatoloji uzmanı (H.A.) erkeklerin ayak tırnaklarından örnek alıp OM mevcudiyetini araştırdı.

Bulgular: Çalışmaya kabul edilen 95 hastanın IIEF-5 skorlarına bakılarak 22'sinde (\%23.1) hafif, 20 'sinde (\%21) orta ve 53'ünde (\%55.9) ciddi düzeyde ED bulunduğu saptandı. Sigara kullanma öyküsü ciddi ED grubunda daha fazla idi $(p<0.001)$. Toplam 32 (\%33.7) hastada OM bulunduğu tespit edildi. Ancak, ED şiddeti ile OM mevcudiyeti arasında bir ilişki saptanmadı ( $p>0.114)$.

Sonuç: Erektil disfonksiyon ile OM hastalığı sıklıkla bir arada görülebilmektedir. Ancak ED şiddeti ile bir ilişkisi saptanmamıştır.

Anahtar Sözcükler: Onikomikozis, Erektil disfonksiyon, Etiyoloji 


\section{INTRODUCTION}

Erectile Dysfunction (ED), which has been recently diagnosed in thousands of men around the world, is defined as the inability of a man to achieve and/or maintain sufficient penile erection for at least 6 months. Penile erection occurs as a result of increased arterial blood flow and decreased venous blood flow. All the factors that cause damage to these mechanism result in ED. It has also been shown that atherosclerosis, which negatively affects all vascular structures, begins to influence penile arteries, before coronary and carotid arteries (1). Atherosclerosis causes endothelial dysfunction and disrupts the nitric oxide synthesis process, leading to inadequate expansion of penile arteries and consequently to ED (2).

Onychomycosis (OM) is a fungal infection of the nail and its bed. It is seen between $2 \%$ and $11 \%$ of the healthy population and includes some risk factors such as endothelial dysfunction that gives cause for atherosclerosis, decreased microcapillary circulation, oxidative stress and inflammation, as in ED (3-5.) Peripheral artery diseases (PAD) are also closely related to atherosclerotic risk factors such as $\mathrm{ED}$ and OM. PAD, which can be frequently seen with cardiovascular and cerebrovascular diseases, is more common among those who are in advanced age, and have smoking history, hyperlipidemia, hypertension, and diabetic, but it is much more prevalent among male patients $(1,2)$. Studies have reported that patients with symptomatic and asymptomatic PAD have an equal risk of early death (6). Therefore, when patients within the asymptomatic period PAD are admitted to the hospital due to other diseases with common risk, the diagnosis of PAD will help to reduce the risk of premature death (7). As it has been shown that $\mathrm{OM}$ can be an independent marker for PAD, the close relationship between ED and PAD has also been shown in many studies (8-10). In a patient admitted to the outpatient clinic due to $\mathrm{OM}$ or ED, PAD must be considered and the referral of the patient to the relevant branch will be an important step for the patient's future life.

As a result of the literature review, no study was found evaluating the association of ED and OM, although they have common risk factors. In this study, we tried to reveal whether there is OM association in men who applied to the urology outpatient clinic because of ED.

\section{MATERIALS and METHODS}

The study was carried out under the ethical principles of the Declaration of Helsinki and was approved by the Local Ethics Committee of Karabük University (1/4 / 2019- 4/19). Between April 2019 and April 2020, the male patients who applied to Karabük University Faculty of Medicine Department of Urology polyclinic with ED complaints, met the study criteria and accepted to participate in the present study.
Sociodemographic form and the International Index of Erectile Function (IIEF) -5 form for the evaluation of sexual functions were filled by the patients who met the inclusion criteria and accepted to partake in the study both in writing and orally. In this study, we classified the patients according to the IIEF-5 scores, as done by Spessoto et al. (11), for ease of grouping. In the ED classification, those with the IIEF-5 score of 25 and above is normal; $17-24$ score range is mild; 11-16 score range is moderate and scores of 10 and below are considered as severe ED. After form-filling process, the toenails of the patients were evaluated by a dermatologist. Samples taken from the nails of patients with clinical suspicion of OM were prepared with potassium hydroxide and evaluated under a microscope to identify fungal filaments.

The exclusion criteria were the absence of a history of regular sexual intercourse, recent genital surgery, any psychiatric and/or neurological disease, chronic heart and/or respiratory diseases, chronic kidney disease, any oncological disease, and previous OM treatment and/or having nail disease apart from OM.

Continuous data are given as Mean \pm Standard Deviation. Categorical data are given as percentage (\%). Shapiro Wilk's test was used to investigate the compliance of the data to normal distribution. One-way analysis of variance (One-Way ANOVA) was used for the cases with three or more groups in comparison of the groups showing normal distribution. Pearson Chi-Square and Pearson's Exact Chi-Square analysis were used in the analysis of the cross tables created. IBM SPSS Statistics 21.0 (IBM Corp. Released 2012. IBM SPSS Statistics for Windows, Version 21.0. Armonk, NY: IBM Corp.) program was used in the application of the analyzes. $P<0.05$ value was accepted as the criterion for statistical significance.

$G^{*}$ Power (G* Power Ver. 3.0.10, Franz Faul. Kiel University, Deutschland) (12) package program was used to determine the sample size. The sample size was found to be 45 people for a study with 95\% power, Type 1 error (alpha) 0.05 and effect size 0.5 . A total of 95 patients were planned to be included in the study.

\section{RESULTS}

Between April 2019 and April 2020, 147 male patients applied to the Urology Department with the complaint of ED. Of the 132 patients who agreed to participate in the study, 27 patients were excluded from the study because they did not meet the inclusion criteria. Sociodemographic form and IIEF-5 were applied to 105 patients. 10 patients with an IIEF-5 score of 25 and above were not included in the study because ED was not detected. The remaining 95 patients were evaluated by a dermatologist in terms of OM.

When classified according to IIEF-5 scores, 22 (23.1\%) patients were in the mild group, $20(21 \%)$ patients were in 
the moderate group, and 53 (55.9\%) patients were in the severe group (Table 1). Smoking was statistically higher in the severe group compared to the other groups ( $p$ $<0.001)$. OM was detected in $33.7 \%$ of 95 ED patients who were included in the study. When the presence of OM was examined in all 3 groups, no statistical difference was found between the groups in terms of ED severity $(p=0.11)$.

\section{DISCUSSION}

Diseases such as hypertension, diabetes, dyslipidemia, and smoking are common risk factors for PAD, ED and OM. However, endothelial dysfunction is the most important underlying cause of all three diseases. (13-15) All of the above mentioned risk factors and endothelial dysfunction play a huge role in the development and progression of atherosclerosis. Cardiovascular diseases, one of the most important causes of death in the world, are caused by atherosclerosis. Since cardiovascular diseases may not cause symptoms until they cause hardening of systemic arteries, they are described as 'silent killers' (16). Therefore, it is very important that these types of diseases are caught in the asymptomatic period.

In the literature, $48 \%$ of men with ED had cardiovascular disease and $46 \%$ had coronary heart disease (17). In a study by Kumagai et al. (18) ED was defined as an independent risk factor for PAD. On the other hand, Montorsi et al. (19) showed that men who started to show symptoms of ED were more likely to show the symptoms of cardiovascular disease over a period of 2-3 years. Other studies have shown that the severity of ED symptoms is positively correlated with atherosclerotic heart disease status, and the presence of $E D$ is an independent risk factor for cardiovascular diseases $(1,20)$. Peripheral circulation disruption is one of the important risk factors in the development of onychomycosis (21). Many studies have also shown that the presence of ED will be a marker for peripheral vascular diseases (22). The fact that circulatory dysfunction is an important etiology for both onychomycosis and ED suggests the possibility of ED in patients with onychomycosis and the development of onychomycosis in patients with ED.

Studies have shown that OM can be an early marker for atherosclerosis and it has a close relationship with atherosclerosis like ED. In the study of Fukunaga et al. (14), the incidence of asymptomatic PAD in patients with OM was found more frequently than in the group without OM. In a study conducted on 127 patients with type-2 diabetes, the presence of $\mathrm{OM}$ and subclinical atherosclerosis was examined; and, it was stated that there might be a relationship between $\mathrm{OM}$ and subclinical atherosclerosis in diabetic patients. OM could be used as a marker for the diagnosis of atherosclerotic vascular diseases. (23) Contrary to this study, although venous insufficiency was found more frequently in patients with OM compared to the control group, no statistical difference was found between the o study groups in terms of PAD (24).

There are many studies reported that dermatological diseases and ED can accompany each other. It has been shown that $81 \%$ of men with systemic sclerosis and $67 \%$ of men with amyloidosis have ED (25). In another study, ED was found in $60 \%$ of men with dermatological disease. (26). The side effects of the drugs used for the disease and thought of skin findings have a negative impact on the partner, since they cause sexual reluctance and loss of confidence. Besides, common etiological factors such as atherosclerosis have been suggested to play a role on the increased frequency of ED (27).

Although OM and ED have been shown to be early markers for atherosclerosis in different studies, there is no study in the literature about the co-occurrence of OM and ED. In this study, to our knowledge, we showed firstly that OM was found in $33.7 \%$ of men with ED. However, no statistically significant relationship was found between the severity of ED and the frequency of OM. Further multicenter study including more patients and control groups is needed to show relationship with ED and OM.

Table 1: Socio-Demographic Characteristics and Incidence of OM in ED Patients

\begin{tabular}{|c|c|c|c|c|c|c|c|}
\hline & & \multirow[b]{2}{*}{ Total $(\mathrm{n}=95)$} & \multirow[b]{2}{*}{$\mathbf{p}$} & \multicolumn{3}{|c|}{ IIEF-5 } & \multirow{2}{*}{$\mathbf{p}$} \\
\hline & & & & Mild $(n=22)$ & Moderate $(n=20)$ & Severe $(n=53)$ & \\
\hline Age (Year) & (Mean \pm S.D) & $51.47 \pm 0.97$ & & $50.50 \pm 0.53$ & $50.82 \pm 0.84$ & $54.48 \pm 1.01$ & $0.102^{*}$ \\
\hline \multirow[t]{2}{*}{ Cigarette n (\%) } & Yes & $63(66.3)$ & \multirow[t]{2}{*}{$<0.001^{* *}$} & $10(45.5)$ & $10(50)$ & $43(81.1)$ & \multirow{2}{*}{$<0.001^{* * *}$} \\
\hline & No & $32(33.7)$ & & $12(54.5)$ & $10(50)$ & $10(18.9)$ & \\
\hline \multirow[t]{2}{*}{ Diabetes n (\%) } & Yes & $19(20)$ & \multirow[t]{2}{*}{$0.082^{\star *}$} & $3(13.6)$ & $4(20)$ & $12(22.6)$ & \multirow{2}{*}{$0.097^{\star * *}$} \\
\hline & No & $76(80)$ & & $19(86.4)$ & $16(80)$ & $41(77.4)$ & \\
\hline \multirow{2}{*}{ Onychomycosis n (\%) } & Yes & $32(33.7)$ & \multirow[t]{2}{*}{$0.176^{\star *}$} & $6(27.3)$ & $9(45)$ & $17(32.1)$ & \multirow{2}{*}{$0.114^{\star *}$} \\
\hline & No & $63(66.3)$ & & $16(72.7)$ & $11(55)$ & $36(67.9)$ & \\
\hline
\end{tabular}

* One-Way Analysis of Variance, ${ }^{* *}$ Pearson Chi-Square Analysis, ${ }^{* * *}$ Fischer (Exact) Chi-Square Analysis 
Single-center study being said, if there is insufficient number of patients included in the study, the questionnaire evaluated the results of patients with relatively subjective, that may be a risk factor for OM in the patient's self-care ability of assessment; factors that we restrict our study.

\section{Conclusion}

Early detection of atherosclerosis markers such as ED and OM will play an important role in preventing the progression of atherosclerosis and other complications. That is why; OM should be kept in mind in the patients presenting the complaint of erectile dysfunction, and these patients should be directed to the relevant branch.

\section{Author Contrubitons}

Concept: Özer Baran, Design: Coşkun Kaya, Data collection or processing: Özer Baran, Habibullah Aktaş, Analysis or Interpretation: Aykut Aykaç, Literature search: Aykut Aykaç, Coşkun Kaya, Writing: Özer Baran, Approval: Habibullah Aktaş.

\section{Conflicts of Interest}

The authors declare that there is no conflict of interest

Financial Support

The authors declare that there is no financial support.

\section{Ethical Approval}

The study was carried out under the ethical principles of the Declaration of Helsinki and was approved by the Local Ethics Committee of Karabük University. (1/4 / 2019- 4/19)

\section{Peer Review Process}

Extremely peer-reviewed.

\section{REFERENCES}

1. Gandaglia G, Briganti A, Jackson G, Kloner RA, Montorsi $\mathrm{F}$, Montorsi $\mathrm{P}$, Vlachopoulos $\mathrm{C}$. A systematic review of the association between erectile dysfunction and cardiovascular disease. Eur Urol 2014;65:968-978.

2. Maas R, Schwedhelm E, Albsmeier J, Boger RH: The pathophysiology of erectile dysfunction related to endothelial dysfunction and mediators of vascular function. Vasc Med 2002; 7: 213-215.

3. Sigurgeirsson B, Baran R. The prevalence of onychomycosis in the global population - A literature study. J Eur Acad Dermatol Venereol 2014;28(11):1480-1491.

4. Kampoli AM, Tousoulis D, Briasoulis A, Latsios G, Papageorgiou N, Stefanadis C. Potential pathogenic infl ammatory mechanisms of endothelial dysfunction induced by type 2 diabetes mellitus. Curr Pharm Des 2011;17: 4147-4158.

5. Tousoulis D, Kampoli AM, Stefanadis C. Diabetes mellitus and vascular endothelial dysfunction: Current perspectives. Curr Vasc Pharmacol 2012;10:19-32.
6. Jude EB, Eleftheriadou I, Tentolouris N. Peripheral arterial disease in diabetes - a review. Diabet Med 2010; 27: 4-14.

7. Ferket BS, Spronk S, Colkesen EB, Hunink MG. Systematic review of guidelines on peripheral artery disease screening. Am J Med 2012;125:198-208.

8. Gupta AK, Gupta MA, Summerbell RC, Cooper EA, Konnikov $\mathrm{N}$, Albreski D, MacDonald P, Harris KA. The epidemiology of onychomycosis: possible role of smoking and peripheral arterial disease. J Eur Acad Dermatol Venereol 2000;14:466469.

9. Hotaling JM, Walsh TJ, Macleod LC, Heckbert S, Pocobelli G, Wessells $\mathrm{H}$, White E. Erectile dysfunction is not independently associated with cardiovascular death: Data from the vitamins and lifestyle (VITAL) study. J Sex Med 2012; 9: 2104-2110.

10. Nehra A, Jackson G, Miner M, Billups KL, Burnett AL, Buvat J, Carson CC, Cunningham GR, Ganz P, Goldstein I, Guay AT, Hackett G, Kloner RA, Kostis J, Montorsi P, Ramsey M, Rosen R, Sadovsky R, Seftel AD, Shabsigh R, Vlachopoulos C, Wu FC. The Princeton III consensus recommendations for the management of erectile dysfunction and cardiovascular disease. Mayo Clin Proc 2012; 87:766-778.

11 Spessoto LC, Facio FN Jr, de Arruda JG, Arruda PF, Gatti M, Antoniassi TS, Facio MF, de Godoy JM. Association of hypertension with erectile function in chronic peripheral arterial insufficiency patients. J Clin Med Res 2016;8(8):582-584.

12. $G^{*}$ Power Ver. 3.0.10, Franz Faul. Kiel University, Deutschland Available: https://www.psychologie.hhu.de/arbeitsgruppen/ allgemeine-psychologie-und-arbeitspsychologie/gpower

13. Giuliano F. New horizons in erectile and endothelial dysfunction research and therapies. Int $\mathrm{J}$ Impot Res 2008; 20:2-8.

14. Fukunaga A, Washio K, Ogura K, Taguchi K, Chiyomaru K, Ohno Y, Masaki T, Nagai H, Nagano T, Oka M, Nishigori C. Onychomycosis as a warning sign for peripheral arterial disease. Acta Derm Venereol 2013;93:747-748.

15. Çinar Ö, Bolat MS. Erektil disfonksiyon hastalarına multidisipliner yaklaşım gerekir mi? Türk Diyab Obez 2020;3: 239-243.

16. Go AS, Mozaffarian D, Roger VL, Benjamin EJ, Berry JD, Borden WB, Bravata DM, Dai S, Ford ES, Fox CS, Franco S, Fullerton HJ, Gillespie C, Hailpern SM, Heit JA, Howard VJ, Huffman MD, Kissela BM, Kittner SJ, Lackland DT, Lichtman $\mathrm{JH}$, Lisabeth LD, Magid D, Marcus GM, Marelli A, Matchar DB, McGuire DK, Mohler ER, Moy CS, Mussolino ME, Nichol G, Paynter NP, Schreiner PJ, Sorlie PD, Stein J, Turan TN, Virani SS, Wong ND, Woo D, Turner MB; American Heart Association Statistics Committee and Stroke Statistics Subcommittee. Heart disease and stroke statistics -2013 update: A report from the American Heart Association. Circulation 2013;127: 6-245.

17. Dong JY, Zhang YH, Qin LQ. Erectile dysfunction and risk of cardiovascular disease: Meta-analysis of prospective cohort studies. J Am Coll Cardiol 2011;58:1378-1385.

18. Kumagai H, Yoshikawa T, Myoenzono K, Kosaki K, Akazawa N, Asako ZM, Tsujimoto T, Kidokoro T, Tanaka K, Maeda S. Sexual function is an indicator of central arterial stiffness and arterial stiffness gradient in Japanese adult men. J Am Heart Assoc 2018;7(10).e007964. 
19. Montorsi P, Ravagnani PM, Galli S, Rotatori F, Veglia F, Briganti A, Salonia A, Dehò F, Rigatti P, Montorsi F, Fiorentini C. Association between erectile dysfunction and coronary artery disease. Role of coronary clinical presentation and extent of coronary vessels involvement: The COBRA trial. Eur Heart J 2006;27:2632-2639.

20. Shin D, Pregenzer G, Gardin JM. Erectile dysfunction: A disease marker for cardiovascular disease. Cardiol Rev 2011; 19: 5-11.

21. Scher RK, Rich P, Pariser D, Elewski B. The epidemiology, etiology, and pathophysiology of onychomycosis. Semin Cutan Med Surg 2013;32(2 Suppl 1):S2-4.

22. Blumentals WA, Gomez-Caminero A, Joo S, Vannappagari V. Is erectile dysfunction predictive of peripheral vascular disease? Aging Male 2003;6(4):217-221.
23. Onalan O, Adar A, Keles H, Ertugrul G, Ozkan N, Aktas H, Karakaya E. Onychomycosis is associated with subclinical atherosclerosis in patients with diabetes. Vasa 2015;44:59-64.

24. Ozkan F, Ozturk P, Ozyurt K, İncı MF, Kalender AM, Bakan B, Yuksel M. Frequency of peripheral arterial disease and venous insufficiency in toenail onychomycosis. J Dermatol 2013;40: 107-110.

25. Ermertcan AT, Temeltaş G. Dermatologic diseases and their effects on male sexual functions. J Dtsch Dermatol Ges 2010; 8: 592-597.

26. Goulding JM, Price CL, Defty CL, Hulangamuwa CS, Bader E, Ahmed I. Erectile dysfunction in patients with psoriasis: Increased prevalence, an unmet need, and a chance to intervene. Br J Dermatol 2011;164:103-109.

27. Duarte GV, Calmon H, Radel G, de Fátima Paim de Oliveira M. Psoriasis and sexual dysfunction: links, risks, and management challenges. Psoriasis (Auckl) 2018;8:93-99. 